\title{
STRATEGIES FOR THE MANAGEMENT OF BUILT HERITAGE LINKED TO MAINTENANCE AND MONITORING. CASE STUDY OF THE SAN ROQUE NEIGHBORHOOD, CUENCA, ECUADOR
}

\author{
M. C. Achig-Balarezo a, L. Vázquez ${ }^{a}$, M. G. Barsallo ${ }^{\text {a, J. C. Briones }}{ }^{\text {a, J. Amaya }}{ }^{\text {a. }}$ \\ aUniversidad de Cuenca, Facultad de Arquitectura y Urbanismo, Av. 12 de Abril y Agustín Cueva, Cuenca, Ecuador - \\ (cecilia.achig,gabriela.barsallo,juan.briones, jorge.amaya@ucuenca.edu.ec, lvazqueztorres@yahoo.com.
}

\author{
Commission II, WG VI/4
}

KEY WORDS: Heritage, monitoring strategies, maintenance, governance, documentation.

\begin{abstract}
:
The rehabilitation of heritage sites, as well as the implementation of monitoring and control strategies is fundamental for its conservation. In the case of Cuenca, a World Heritage City, a maintenance campaign in the traditional neighborhood of San Roque was carried out in 2014. The objective was to undertake maintenance actions on roofs and façades as well as on elements at risk. The campaign process was developed keeping in mind the cycle or phases of preventive conservation: anamnesis, diagnosis, therapy and control (ICOMOS, 2003). At the end of the maintenance campaign an impact assessment was undertaken and monitoring tools were handed out to the community in order to strengthen the citizen participation in the preservation of built heritage. The experience of the maintenance campaign unveiled a series of lessons that have been evaluated in the present investigation, being the main objective the strengthening of the processes of governance and documentation through the formulation of strategies inherent to the maintenance of heritage buildings. In this process it is shown that the participation of citizens is a strategic factor for the sustainable development of maintenance campaigns, which allow for the preservation of historical sites for future generations.
\end{abstract}

\section{INTRODUCTION}

Maintenance actions in heritage buildings are inserted within preventive conservation, whose meaning is reflected in the adage of Erasmus of Rotterdam: "To prevent is better than to cure", a phrase applied in the field of medicine, visualizing the good state of a prudent person, who maintains his good health through practices of daily care.

The San Roque Maintenance Campaign (January - March 2014) is an exercise in the application of maintenance and monitoring actions in a set of heritage buildings of a neighborhood in Cuenca, a city included in the World Heritage List in the year 1999. It is necessary to analyze and evaluate the process that began in 2012 and that has left a significant impact on the city.

The applied methodology in the present article starts from the definition of the terms preventive conservation, maintenance and monitoring. Subsequently, the main activities, roles and territorial actors in each phase of the application of the Maintenance Campaign in San Roque are emphasized. These phases (anamnesis, diagnosis, therapy and control) are inserted within the preventive conservation cycle proposed by ICOMOS (2003). Finally, an evaluation of the maintenance campaign is carried out and a proposal is presented based on strategies for the management of built heritage, emphasizing the control, monitoring and evaluation phase, which can be used as support for interventions in similar future projects.

\subsection{Preventive conservation: maintenance and monitoring}

The modern concept of preventive conservation is based on the reflections generated over time. In the 19th century Adolphe Napoleon Didron raised an important principle: "Conserve as much as possible, repair as little as possible, not restore at any price" (Astudillo, 2011). Although the theme of prevention (linked to maintenance) has been mentioned since the Athens
Charter, preventive conservation, especially at the international level, has gained importance in the last decade "(Cardoso, 2009).

The purpose of preventive conservation is to anticipate the deterioration of assets, through the application of a set of measures that aim to avoid and minimize deterioration or losses, in order to preserve them for future generations (Achig, Jara, Cardoso \&Van Balen, 2014).

The UNESCO Chair PRECOM ${ }^{3}$ OS (Preventive Conservation, Monitoring and Maintenance of Monuments and Sites) has stimulated in several parts of the world the development of an attitude of prevention around four fundamental pillars that sustain a sustainable development: economic, cultural, environmental and social. A preventive approach to conservation and maintenance is committed to the early identification of possible actions, which are identified through periodic observation and monitoring processes, in order to reduce or avoid major interventions that put assets at risk or require large investments of money (Garcia, Cardoso \& Van Balen, 2014). The protection of heritage assets through preventive conservation requires the participation of a larger number of people in relation to curative actions, which necessarily implies the participation of a committed community (Van Balen, 2009). A Preventive Conservation Plan is based on the identification of values, in the documentation of the information, which must be introduced and ordered in databases so that they can be updated periodically (Heras, Wijffels, Cardoso, Vandesande, Santana, Van Orshoven, Steenberghen\&Van Balen, K. 2013).

The methodology for the study of damages in heritage structures used by ICOMOS (2003), anamnesis, diagnosis, treatment and control, was used to determine the phases of a Preventive Conservation Plan (Achig et al, 2014), which synthesizes the process developed in the San Roque Maintenance Campaign, object of analysis of the present investigation. In Phase I the 
project was proposed and the heritage values of the sector were determined, in Phase II a diagnostic study is carried out, while Phases III and IV included the maintenance and monitoring actions. In order to achieve cost effectiveness and a minimal impact on architectural heritage, it is usually necessary that these steps are repeated in an iterative process (ICOMOS, 2003), as is shown in figure 1.

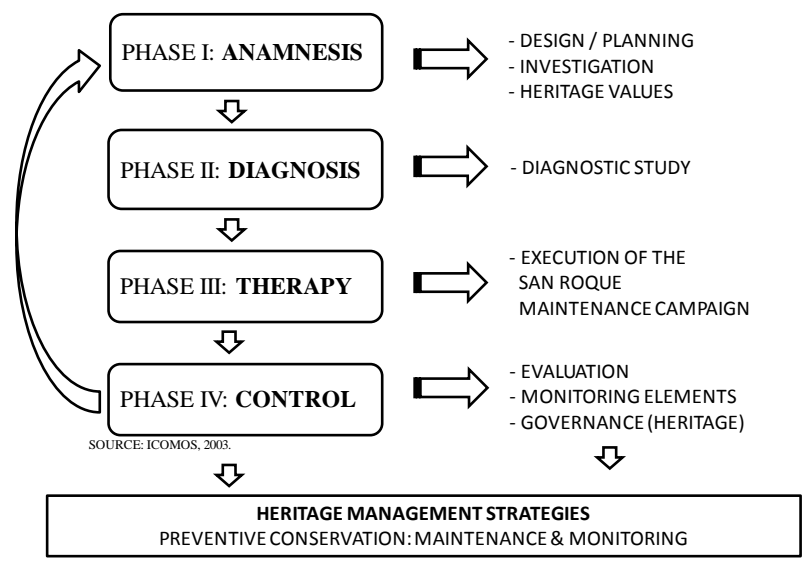

Figure 1: Phases of the Preventive Conservation Plan applied in the San Roque Maintenance Campaign

Source: ICOMOS 2013

Elaboration: vlirCPM project

With this theoretical basis, the case study was introduced: the maintenance campaign of the heritage buildings of San Roque, which was developed following the process proposed by ICOMOS over a period of approximately two years. The intervention focused mainly on the physical maintenance of the buildings, which was completely fulfilled. However, it is necessary to expand this vision to other areas and encourage discussions. For this reason, the present article emphasizes the importance to create learning processes based on this methodology, focusing on the influence of the citizenship in the different phases of preventive conservation, promoting a proactive attitude from the planning, execution and evaluation phases of the project that guarantees the sustainability of this type of experiences.

\section{METHODOLOGY}

The methodology proposed in the present investigation starts from the analysis of the different activities carried out in the maintenance campaign of San Roque in the phases I, II and III (anamnesis, diagnosis and therapy). In these phases several tools were used to determine the heritage values of the neighborhood, such as the Nara matrix (Van Balen, 2008), the damage diagnostic card, damage atlas, surveys and interviews with beneficiaries and key stakeholders as well as the realization of workshops with the community. Subsequently, an evaluation of the maintenance campaign was carried out in phase IV (control), which showed that, through the lessons learned in the different phases, it was necessary to strengthen the process of governance and documentation.

\section{THE EXPERIENCE OF THE SAN ROQUE MAINTENANCE CAMPAIGN IN ITS PHASES I, II III}

The San Roque Campaign was applied to 22 buildings during 9 week period (January - March 2014) and was made possible through agreements between the University of Cuenca, public institutions as well as private and local community participation. The University of Cuenca, through the project vlirCPM (World Heritage City) included a group of about 64 people of different expertise, such as researchers-teachers, students, masons and heritage experts, which led to a connection of the academy with the community in the area of Heritage Conservation (Achig et al, 2014).

The main objective was to carry out emergency maintenance on roofs, façades and elements at risk, and based on this to implement cyclical monitoring as part of its Preventive Conservation. Other objectives were to commit and to encourage in the community (neighbors, owners, tenants, administrators) the care of heritage, to understand the processes of monitoring and maintaining heritage, to apply research tools in a real world environment, to revitalize the 'minga' processes (collective unpaid work) as one of the intangible assets of our society and to evaluate the processes and the results of the Maintenance Campaign before, during and after its execution.

\subsection{Phases of the San Roque Maintenance Campaign 3.1.1 Phase I -ANAMNESIS: Heritage values and justification of the study area.}

San Roque is one of the historical districts of Cuenca, recognized by UNESCO as a World Heritage Site. It is located in the building block between the streets El Farol, Av. Loja and Av. 12 de Abril, next to the University of Cuenca (Fig. 2) and on the opposite bank of the river Tomebamba with respect to the historical center. San Roque fulfilled the role of access and exit to the city with interesting visual relations towards the Historical Center of Cuenca. The decision to work in San Roque was due to several factors: the heritage value of its buildings, the role that the church could play in the process of community organization, the availability of the neighbors to participate in this process and to become a study area of the vlirCPM project. ${ }^{1}$ (Achig et al, 2014) The San Roque neighborhood contains both material as well as immaterial heritage of value to Cuenca. It is rich in legends, traditions, religious festivals and gastronomy. There are still vernacular buildings made with traditional materials and constructive systems: adobe, bahareque, tile and wood in deck structure and carpentry. These historical, technical, aesthetic and social values were identified, using the Nara Grid (Van Balen, 2008), as outstanding elements of the building block.

\subsubsection{Phase II - DIAGNOSIS: Diagnostic study}

An adequate diagnosis allows the identification of damages that put at risk the stability of the heritage assets, which can be avoided through maintenance. In the Maintenance Campaign of San Roque, situations of imminent risk were determined in several buildings. Within this phase the following activities were carried out: A) the application of diagnostic cards for which it was necessary to conduct surveys of all sites, a fundamental task within the monitoring process. B) An enhancement study and a proposal of the historical colors (Achig \& Paredes, 2001) for an adequate maintenance of the façades, especially in the case of

management of world heritage sites in southern Ecuador by generating tools and the dissemination of knowledge.
The vlirCPM (VlaamseInteruniversitaireRaad - City Preservation Management) project aims to develop scientific bases and provide high-level education to contribute to the goal of improving the 
coatings made of earth. The owners formed a fundamental part of this process. C) Conducting surveys and interviews with key stakeholders before, during and after the Maintenance Campaign, in order to understand the residents' perceptions about their neighborhood, their maintenance practices and their views on heritage, as well as a real evaluation of the campaign.

In December 2013, as of the delivery of the document "Project of the San Roque Maintenance Campaign", agreements were signed between the University of Cuenca, the Municipality and the owners.

\subsubsection{Phase III - TREATMENT: Intervention in the Maintenance Campaign.}

With the diagnostic study completed at the beginning of 2014, the San Roque Maintenance Campaign was implemented. Five working groups were formed, each in charge of 4 or 5 buildings. Each group had a leader (technician of the vlirCPM project), two students as construction residents, one master teacher, three masons and five members of the Armed Forces. The community promised to pay an economic contribution to cover part of the cost of the workforce. The cost per owner was $\$ 40$ per day for the duration of the intervention on their property.

The maintenance of the façades involved: replacement of plasters and coverings of earth, placement of gutters, replacement of glass, maintenance of carpentry, application of paint and color on walls and carpentry elements, plus the removal of cables.

\section{EVALUATION AND STRATEGIES FOR THE MANAGEMENT OF HERITAGE LINKED TO THE CONTROL AND MONITORING PHASE}

In a study carried out in 2016 (Achig, Barsallo, Briones, \& Cardoso, 2016), a methodology was laid out to determine the condition of the buildings in the San Roque Maintenance Campaign. This study determined the effectiveness of the intervention measures (phase III) raised in phase IV corresponding to the control and monitoring of the maintenance campaign carried out in 2014.

Figure 2 shows the change of the condition of the buildings to "good" as compared to their condition in the diagnosis and control phases.

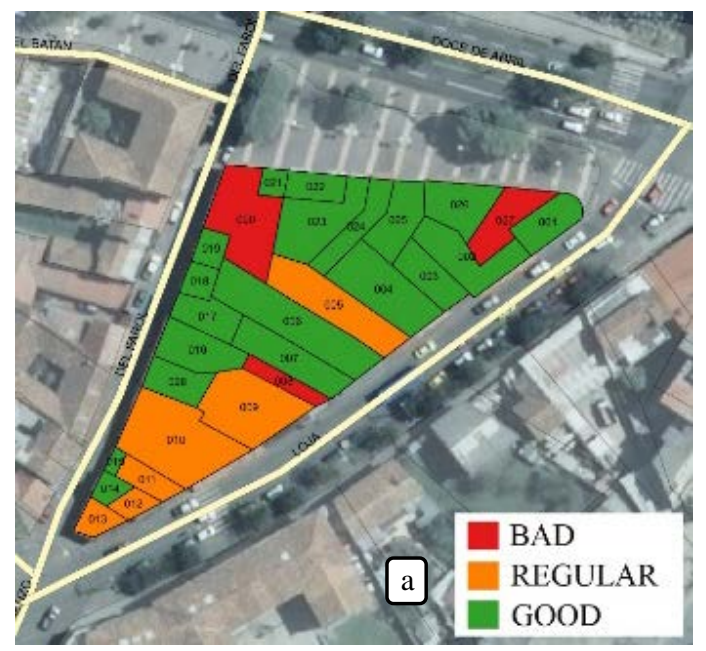

Figure 2a: The condition of the buildings in the Diagnosis phase, before the Campaign (2012). Source: vlirCPM project.

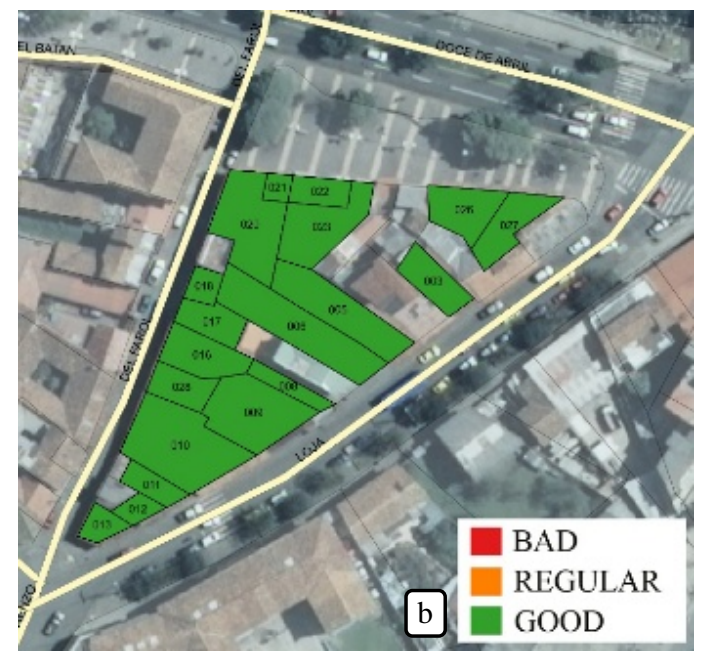

Figure 2b: The condition of the buildings in the Diagnosis phase, after de Campaign (2014). Source: vlirCPM project.

\subsection{Façade monitoring}

As part of the monitoring process of the façades carried out by the vlirCPM project, the sections facing the Av. 12 of April in the Square of the Farol are analyzed. In the diagnostic phase (2013) and after the execution of the campaign (2014), a photographic survey was carried out to present color proposals as part of the façade enhancements. During the monitoring and control phase, several visits were made to the site in March 2016 and January 2017. These visits showed that vandalism, in the form of graffiti, had negatively affected the appearance of the façades. Also a lack of daily maintenance by the owners was observed, which can be attributed to several factors: lack of resources, lack of interest, lack of ownership of their buildings. It is important to indicate that of the 9 buildings of the indicated section 30\% has not had maintenance on their façades. As an example of the monitoring process, figure 3 shows a building and its deterioration due to a lack of maintenance.
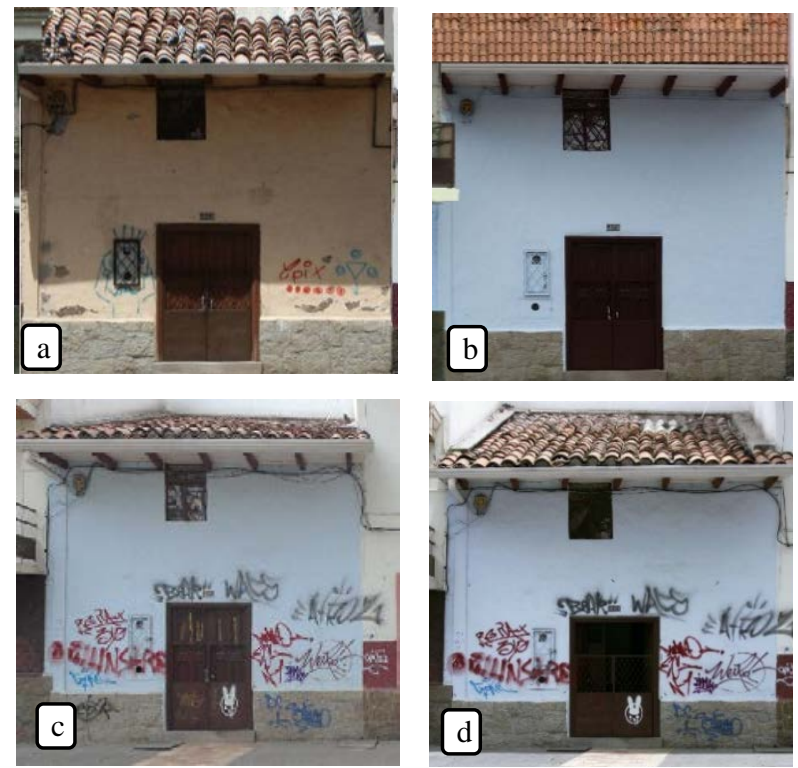

Figure 3: a) Before the Campaign (2012) b) After de Campaign (2014), c) monitoring (2016), d) monitoring (2017) Source: vlirCPM project 


\subsection{Documentation techniques for monitoring. Information flows}

The preservation of built heritage requires qualitative data to be considered as quantitative, aspects that allow both the physical characteristics as well as the value of the heritage building to be covered. At present, there are different documentation techniques that provide detailed information of physical characteristics, such as photogrammetry of façades and roofs, or laser scanning of buildings. The use of UAVs for the acquisition of high-quality images on rooftops requires the use of new techniques to process these data. Different studies (Hebel \&Stilla, 2008), (Qin, Huang, Gruen, \& Schmitt, 2015), (Zhang, Qin, Huang, \& Liu, 2015) outline the use of geometric information segmentation, reconstruction and extraction techniques from multispectral or conventional images.

Based on the San Roque Maintenance Campaign, a proposal is made for the flow of information that is presented in each of the phases of the preventive conservation cycle previously explained. This proposal allowed for the evaluation and discussion of the successes and the aspects to be strengthened in future maintenance experiences of built heritage.

\subsubsection{Phase I- Anamnesis:}

It is important to research the historical information related to the original state of the structures and their consecutive stages, as well as the techniques and the skills used in its construction, reconstructions, modifications, additions, restorations and structural changes. All this information leads to the determination of the present condition of the buildings (ICOMOS 2014). In the San Roque campaign, due to the scale of the buildings and the lack of information, it was not possible to carry out a historical investigation of each individual building, but instead a historical investigation of the building block as a whole was carried out.

\subsubsection{Phase II - Diagnosis:}

This is the process of identifying the nature and the cause of the damage and decay through observation, investigation (including mathematical models) and historical analysis, and the conclusions derived from these (ICOMOS 2014).

\section{Strategies:}

Planimetric survey of the building: this process aims to assign an identifier to each of the spaces, coded in the following structure: Block-Level-Environment-Element-Subelement.

Data collection by means of laser scanning of the environment for certain monumental buildings, such as churches, generating clouds of points representing a three-dimensional model of the building.

Registration cards: these cards describe the general characteristics of the building, such as: architectural typology, site, location, year of construction, number of floors and valuation. The damage registration card is a support tool to determine the condition of a building through the analysis of its damages and its possible causes. For its application, it is necessary to have the surveys updated, geo-referenced and each space clearly coded (Achig, et al 2016). In addition, the support of the Damage Atlas allowed for an adequate identification of damages.
Considering the objectives and scope of the research, as well as the scale of the buildings, it was not necessary to use a laser scanner during the maintenance campaign. The other mentioned tools were sufficient to determine the condition of the buildings through the use of the damage registration.

\section{Decision making:}

The damage registration card contains a recommendation about the frequency of monitoring and the need for intervention. This suggestion is related to the judgment of the expert conducting the inspection. The evaluation of the condition of the buildings was determined through a mathematical model, based on the magnitude of the damage and the state of their conservation. (Achig et al, 2016)

Using the planimetric information, damage registers and their topological relationship, it is possible to identify environments that could require immediate intervention. This type of spatial queries trigger factors such as risk, based on the variables: damage, materiality and location, as shown in figure 4.

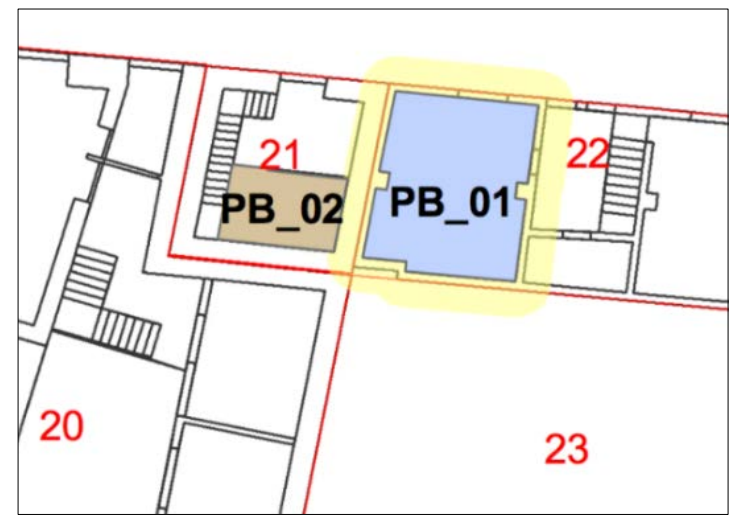

Figure 4: Damage in various elements in continuous environments. Source: vlirCPM project

\subsubsection{Phase III - Therapy:}

This phase refers to "the choice of remedial measures in response to the diagnosis.” (ICOMOS, 2014)

The therapy contemplates the application of a work progress card. All the information of this phase and the previous phases must be collected in a database for its respective analysis. The idea is to evaluate if the intervention measures have mitigated the cause of the problem. It is necessary to monitor each of the intervention measures, making sure that the integrity of the factors that generate heritage value, such as its materiality, typology, and history, is maintained.

\subsubsection{Phase IV - Control:}

In this phase, cyclical and regular monitoring actions are undertaken, such as the implementation of strategies for a preventive conservation plan. During and after the intervention (Phase III - Therapy), checks must be carried out to determine damages, values and safety levels. Control activities should be documented and preserved as part of the construction history, providing feedback to all previous phases. The results show a table which outlines the documentation tools present in the control and monitoring phase. As an example, the importance of the maintenance booklet tool is shown below. 
The vlirCPM project (University of Cuenca) has produced 12 maintenance booklets (figure 5) focused on solving the most common damages in different building elements, such as: roofs, walls of adobe and bahareque, plaster, painting, etc. These booklets use every day language and are a tool to be used by the owners to help them with the monitoring of their buildings.
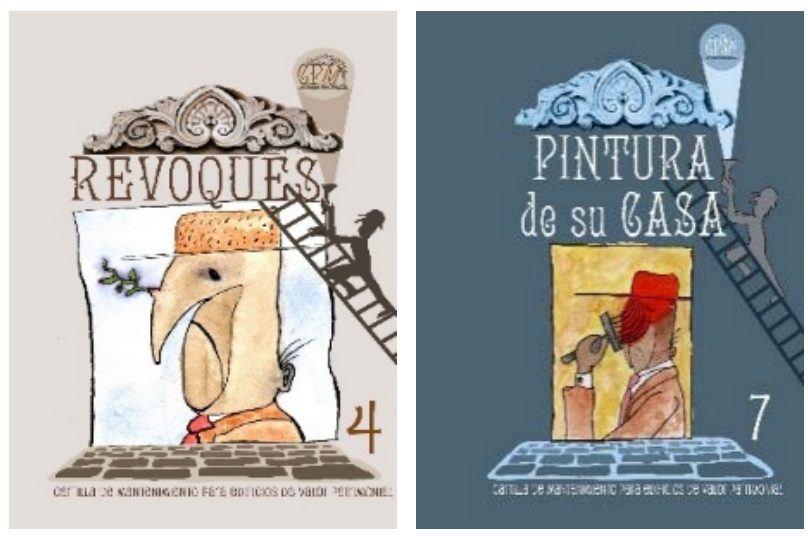

Figure 5: maintenance booklets Source: vlirCPM Project

Two booklets (Wood - Roofs) were initially given to the beneficiaries of the San Roque Maintenance Campaign as a monitoring process undertaken by the vlirCPM project. It is proposed that for subsequent maintenance campaigns all of the booklets are handed out and that the actions to be carried out by the owners are checked and followed up.

The San Roque campaign successfully met its objective of carrying out maintenance actions on façades, decks and emerging elements. In addition some monitoring actions have been carried out, such as the handing out of maintenance booklets. However, one should have a broader vision regarding heritage, generating strategies that allow, on the one hand, greater participation and commitment on the part of the community with regard to the care of heritage and, on the other hand, the involvement of other actors, highlighting the leadership that local authorities must assume to guarantee the successful maintenance and conservation of cultural heritage as a development resource.

\subsection{Governance in relation to heritage: Participatory structure: territorial actors and their roles}

The San Roque Maintenance Campaign emerges as part of the World Heritage City research project(vlirCPM), which combines two axes: the technical and the investigative (described in sections 3.1 and 3.2), which are embedded in the following phases : anamnesis, diagnosis, therapy and control. This process integrates a series of territorial actors with regard to the management and monitoring of built heritage.

Governance seen as a process requires a series of conditions that ensure the participation of territorial actors in decision making to obtain operational results, ascribed to prospective strategies of the territory. One of the first conditions is the leadership of the public sector at different levels - national, regional and local - to take advantage of the various territorial assets linked to heritage management that, from a multilevel regulatory framework, foster timely, effective and efficient cooperation.

Another necessary condition is the existence of a strategic and operative route that helps to organize the local leadership and resources to the diverse development objectives and finally to consider a management and evaluation system of the public policies that allow for the management of achievements and challenges related to the heritage management at different levels (Rhodes, 1997, Maynt, 2001, Prats, 2003, Kooiman, 2003, and CerilloiMartínez, 2005).

UNESCO (2014) conceives heritage governance from the search for a balance between social and economic objectives and between individual and communal goals. The purpose of the governance framework is to promote the efficient use of resources and demand accountability for the management of them. Table 1 illustrates the operational process of shaping territorial governance from a heritage approach.

\begin{tabular}{|c|c|c|c|c|c|c|c|c|}
\hline \multicolumn{5}{|c|}{$\begin{array}{l}\text { STRATEGIC TERRITORIAL CULTURAL PLAN } \\
\text { (STCP) }\end{array}$} & \multicolumn{4}{|c|}{$\begin{array}{c}\text { ANNUAL CULTURAL } \\
\text { OPERATIONAL PLAN (ACOP) }\end{array}$} \\
\hline $\begin{array}{c}\text { Territorial } \\
\text { Cultural Mission } \\
\text { and Vision }\end{array}$ & \multicolumn{2}{|c|}{$\begin{array}{l}\text { Cultural } \\
\text { policy }\end{array}$} & $\begin{array}{c}\text { Strategic } \\
\text { cultural axis }\end{array}$ & $\begin{array}{c}\text { Strategic } \\
\text { cultural goals }\end{array}$ & $\begin{array}{c}\text { Cultural } \\
\text { plans }\end{array}$ & \multicolumn{2}{|c|}{$\begin{array}{c}\text { Cultural } \\
\text { programs }\end{array}$} & $\begin{array}{c}\text { Cultural projects } \\
\text { (Maintenance } \\
\text { Campaigns) }\end{array}$ \\
\hline \multicolumn{9}{|c|}{ ACTORS (Public-Private-Citizenship or building owners) / Area of Territorial } \\
\hline \multicolumn{2}{|c|}{$\begin{array}{c}\text { PHASE } 0 \\
\text { Design - Planning }\end{array}$} & \multicolumn{2}{|c|}{$\begin{array}{c}\text { PHASE I } \\
\text { Investigation }\end{array}$} & $\begin{array}{l}\text { PHASE II } \\
\text { Diagnosis }\end{array}$ & \multicolumn{2}{|c|}{$\begin{array}{l}\text { PHASE III } \\
\text { Therapy }\end{array}$} & \multicolumn{2}{|c|}{$\begin{array}{c}\text { PHASE IV } \\
\text { Control - Evaluation }\end{array}$} \\
\hline
\end{tabular}

Table 1: Construction process of the territorial governance of heritage. Source: Amaya 2017.

\subsubsection{Evaluation of the San Roque Maintenance Campaign with regard to governance}

The San Roque Maintenance campaign aimed to be a means of strengthening the territorial governance of built heritage, since from its conception and execution as a project, it brought together a greater number of territorial actors with the objective of activating a more ambitious process in terms of the conservation of built heritage as it was to have a Preventive Conservation Plan for the city of Cuenca (Achig et al, 2014).

A detail of the various territorial actors and their respective roles played throughout the development process of the maintenance campaign is given below. The University of Cuenca managed, among others, the economic and technical support of key institutions, supported the execution with qualified labor; technical consultants specialized in heritage, warehouse personnel, and electrical studies. ETAPA (the local telecommunication, potable water and sewage company) collaborated with the burial of their wiring that ran in front of the façades, deteriorating its image. The Salesian Foundation PACES lent its technical-human contingent in activities related to plumbing, metal mechanics and carpentry. It is important to emphasize that the PACES Foundation consists of the pastorallabor education of young people in high risk situations and to integrate them into society. The Government of the province of Azuay collaborated with the management of personnel of the Armed Forces of Ecuador to develop activities related to unskilled labor, such as transport, cleaning, etc. The Regional Electricity Company dealt with the elimination of electrical wiring in disused façades. ECU911 (safety services) helped with first aid and the National Police supported with matters of security.

It is necessary to contemplate that the citizen participation in the campaign was exclusively focused on the owners of the intervened houses, with them having a passive role of observation and validation throughout the planning and execution process. It 
should be mentioned that the campaign did not consider other neighborhood actors (other neighbors, shops, schools, church, etc.) who could have enriched the proposal and triggered a participatory process throughout each of the phases of the maintenance campaign.

It is worth noting the obvious leading role played by the University of Cuenca from the conception up until the evaluation of the maintenance campaign. However, one of the lessons learned was that such institutional dynamism of the university was not reciprocated with public leadership. In fact, the Municipality of Cuenca played a complementary role of financing the campaign. To date, there is no evidence of the implementation of a comprehensive conservation plan for built heritage in Cuenca.

Another experience that reveals the need to reinforce governance linked to the maintenance campaigns is that as a result of the enhancements of the façades of the rehabilitated houses, some buildings became public bars, which has caused problems related to the shrinkage of its population and the loss of the quality of life according to interviews carried out with several neighbors. It shows the importance of a joint work that must be carried out since the conception of these projects between the diverse territorial actors, being the neighbors one of the most important ones to be considered, since with them it is possible to foresee and guarantee subjects that will result in improvements of the habitat and in positioning heritage as a means of improving the quality of life.

\subsubsection{Governance strategies in relation to built heritage linked to maintenance and monitoring}

From the experience of the San Roque Maintenance Campaign, the need to integrate citizens throughout the heritage preservation chain that seeks to involve them from the design, planning and evaluation stages is evident. This strategic contribution can mean the integration of territorial actors in key phases such as monitoring, control and evaluation of heritage conservation policies. Owners and custodians are responsible for the constant monitoring of their building by periodically submitting reports of the state of their building, for which within the documentation are included some tools, such as the maintenance booklets.

In a Preventive Conservation Plan for the city, work must be done jointly with all institutions involved in heritage conservation. Heritage maintenance requires among others permissions, the elaboration and the application of documentation tools. It is a collective, non-individual, work in which the integration of territorial actors is fundamental, each of which will be in charge of activities and responsibilities depending on their competencies and their real capabilities and possibilities.

The participation of the institutions should be more active and should overcome the limitations that were observed in the evaluation of the San Roque Maintenance Campaign. An example is the absence of the Cultural Heritage Institute (INPC) with whom the aim of heritage conservation is shared, and whose staff should be integrated as advisors throughout the process. Within the control, monitoring and evaluation phase, it is proposed to reassess the condition of the buildings and carry out the measurement of impacts in the community. Furthermore, the creation of a community advisory office is suggested, focusing on maintenance and monitoring issues, and on coordinating and integrating all institutions with a common goal of safeguarding its heritage.

\section{RESULTS}

Table 2 can be used as a guide for future similar maintenance projects, summarizing the control, maintenance and evaluation phase, the activities, tools, actors and roles that different public and private institutions should play.

\begin{tabular}{|c|c|c|c|}
\hline \multirow{2}{*}{ ACTIVITIES } & \multirow{2}{*}{ DOCUMENTATION TOOLS } & \multicolumn{2}{|r|}{ GOVERNANCE } \\
\hline & & TERRITORIAL ACTORS & \begin{tabular}{l|l} 
S & ROLE TO PLAY
\end{tabular} \\
\hline $\begin{array}{l}\text { - MANAGEMENT, MONITORING, } \\
\text { CONTROL AND EVALUATION } \\
\text {-APPLICATION OF TUOLS }\end{array}$ & $\begin{array}{l}- \text { MAINTENANCE AND } \\
\text { MONITOING FLYRS \& } \\
\text { MANUALS } \\
\text { - REPORTS }\end{array}$ & $\begin{array}{l}\text { - UNIVERSITY } \\
\text { - MUNICIPALITY } \\
\cdot \text { - COMUNITY }\end{array}$ & DESIGN AND APPLY TOOLS \\
\hline • CONDITION ASSESSMENT & $\begin{array}{l}\text { - DAMAGE REGISTRATION } \\
\text { CARD } \\
\text { - MATHEMATICAL MODEL FOR } \\
\text { THE CONDITION ASSESSMENT }\end{array}$ & $\begin{array}{l}\text { - UNIVERSITY } \\
\text { - MUNICIPALITY } \\
\text { - COMUNITY }\end{array}$ & $\begin{array}{l}\text { RESEARCH OF THE BUILDING } \\
\text { CONDITION }\end{array}$ \\
\hline • IMPACT MEASUREM ENT & - SURVEYS & $\begin{array}{l}\text {-UNIVERSITY } \\
\text { - MUNICIPALITY } \\
\text { - COMUNITY }\end{array}$ & $\begin{array}{l}\text { EVALUATE THE IMPACT ON THE } \\
\text { COMMUNITY }\end{array}$ \\
\hline $\begin{array}{l}\text { - CREATION OF AN ADVISORY AND } \\
\text { HERITAGE MANAGEMENT OFFICE }\end{array}$ & ALL OF THE INDICATED & $\begin{array}{l}\text { PUBLLC AND PRIVATE } \\
\text { ACTORS, LED BY THE } \\
\text { MUIICIPAITY } \\
\text { COMUNITY } \\
\end{array}$ & $\begin{array}{l}\text { - COORDINATING BODY OF ALL } \\
\text { INSTITUTIONS } \\
\text { - COMMUNIT COUNELLING WITH } \\
\text { REGRD TO MAINTENANCE AND } \\
\text { MONITORING }\end{array}$ \\
\hline
\end{tabular}

Table 2: Strategies for the management of built heritage linked to the control, maintenance and monitoring phase.

Source: VlirCPM project, 2017

\section{CONCLUSIONS AND RECOMMENDATIONS}

In the management of built heritage, the participation of all public and private actors must take place actively and throughout the entire preventive conservation cycle, starting from the design of the project to the control, monitoring and evaluation phase. The necessary and committed participation of the community in the whole process should be emphasized. The realization of training and co-creation workshops is a mechanism by which citizens must be reached and by which to give them co-responsibility in the preventive conservation processes.

From the beginning, the roles of each of the territorial actors should be clearly defined. This research proposes a participatory structure (governance) that defines management strategies for the control and monitoring applied in maintenance campaigns, considering the leadership of the public actor in the articulation of the various actors with policies and strategies of heritage management.

The University of Cuenca assumed a leading role from the beginning until the evaluation of the San Roque maintenance campaign, which did not favor the shared management of responsibilities by other actors. Being one of the lessons to be considered in future maintenance processes that promote a greater articulation on the part of the different territorial actors and above all, that these campaigns are the result of the leadership of public policies at diverse scales.

The strengthening of governance processes contributes to the management of built heritage not being the exclusive task of certain institutions. As a result of maintenance campaigns, public policies should be developed to allow for interventions that go beyond the physical regeneration of buildings. As a recommendation, other economic, social, environmental and cultural development strategies should be integrated, where the participation of the various territorial actors is the backbone of these public policies, which guarantees the sustainability of these experiences and improves the quality of life.

The preservation of the heritage building through planned maintenance goes hand in hand with the necessity of heritage monitoring through systematic periodic vigilance procedures. 
This way it is possible to identify potential risks that when solved in time could avoid the progress of deterioration that often reaches irreversible situations. As part of heritage management strategies linked to maintenance and monitoring, this article presents documentation tools for each of the phases of the preventive conservation cycle.

The San Roque maintenance campaign allowed for the testing of control and monitoring tools and whose experience could serve as a basis for future similar interventions in the field of the management of built heritage.

In heritage cities the need for the creation of an entity or office that monitors and advises the owners of heritage assets, and where these owners can receive technical assistance about interventions, maintenance as well as monitoring actions, is latent.

\section{REFERENCES}

Achig, M.C., Jara, D., Cardoso., F. \&Van Balen, K., (2014), "Hacia un Plan Piloto de Conservación Preventiva basado en la Campaña de Mantenimiento de San Roque” In ES-TOA revista de la Facultad de Arquitectura y Urbanismo de la Universidad de Cuenca. No. 5, 37-49, Cuenca.

Achig, M. C., Barsallo, M. G., Briones, J. C., \& Cardoso, F. A. (2016). Heritage building's condition at maintenance campaignin San Roque, Cuenca - Ecuador. Conference on Structural Analysis of Historical Constructions, SAHC 2016, 151-157.

Achig, M. \& Paredes, M; (2001) Tesis de Arquitectura: Arqueología del Color: historia, mundo y significación. Estudio y Propuesta para el Centro Histórico de Cuenca”; Cuenca, Ecuador Universidad de Cuenca.

Astudillo, S., (2011), "Los desafíos del Plan de Conservación Preventiva, Monitoreo y Mantenimiento, (PCPM2) en Cuenca, en "II Encuentro PRECOM3OS Seminario. Taller de Tecnologías y restauración de obras en tierra." Universidad de Cuenca, FAUC, Proyecto vlirCPM, Cuenca - Ecuador.

Cardoso, F., (2009),Hacia la formulación de herramientas de gestión del patrimonio de Cuenca: Proceso abierto del proyecto vlirCPM en II Taller Andino para especialistas y administradores de sitios inscritos o no en la lista de Patrimonio Mundial; Proyecto VlirCPM "WorldHeritage City Preservation Management”, Universidad de Cuenca.Cuenca, Ecuador..

Cerillo i Martínez, A. (2005). La gobernanza de hoy: 10 textos de referencia. Madrid, España: Edit. INAP.

García, G,. Cardoso, F,. Van Balen, K,. "The Challenges of Preventive Conservation theory applied to Susudel, Ecuador." in Reflections on Preventive Conservation Theories and Practices. by the Raymond Lemaire International Centre for Conservation. Leuven-Belgium, 2015. 117-129p.

Hebel, M., \& Stilla, U. (2008). Pre-classification of points and segmentation of urban objects by scan line analysis of airborne LiDAR data. International Archives of Photogrammetry, Remote Sensing and Spatial Information Sciences, 37(B3a), 105-110.

Heras, V., Wijffels, A., Cardoso, F., Vandesande, A., Santana, M., Van Orshoven, J., Steenberghen, T., and Van Balen, K. 2013. “A value based monitoring system to support heritage conservation planning”. Journal of Cultural Heritage Management and Sustainable Development, 3(2): 130-147.

ICOMOS charter - principles for the analysis, conservation and structural restoration of architectural heritage (2003)Art. 1.6 Downloaded (http://www.icomos.org/charters/structures_e.pdf, last consulted 01/12/2015)

ICOMOS, Recommendations for the Analysis, Conservation and Structural Restoration of Architectural Heritage(2014). Iscarsah International Scientific Committees on the Analysis and Restoration of Structures of Architectural Heritage Guidelines. Downloaded (https://iscarsah.org/documents/ last consulted 26/04/2016)

Kooiman, J. (2003). Gobernar en gobernanza. Barcelona, España: Edit. Institut Internacional de Governabilitat de Catalunya, (p. 25).

Mayntz, R. (2001). El Estado y la sociedad civil en la gobernanza moderna, Reforma y Democracia. Revista del CLAD, No. 21.

Prats, J. (2003). El concepto y el análisis de la gobernabilidad. Revista Instituciones Y Desarrollo, 15, 239-271

Qin, R., Huang, X., Gruen, A., \& Schmitt, G. (2015). ObjectBased 3-D Building Change Detection on Multitemporal Stereo Images. IEEE Journal of Selected Topics in Applied Earth Observations and Remote Sensing, 8(5), 2125-2137. https://doi.org/10.1109/JSTARS.2015.2424275

Rhodes, R. A. W. (1997), Understanding Governance. Policy Networks, Governance, Reflexivity and Accountability, Buckingham, PA: Open University Press

UNESCO, (2014), Gestión del patrimonio Cultural, Organización de las Naciones Unidas para la Educación, la Ciencia y la Cultura, 7, París, Francia

Van Balen, K. 2008. "The Nara Grid: An Evaluation Scheme Based on the Nara Document on Authenticity”. APT bulletin, 49 (2): 39-45.

Van Balen, K. (2009). Conservación Preventiva en el contexto internacional de la red PRECOM3OS. In C. P. M. P. Vlir (Ed.), II ENCUENTRO PRECOM3OS SEMINARIO TALLER DE TECNOLOGIAS Y RESTAURACION DE OBRAS EN TIERRA. Cuenca.

Zhang, Q., Qin, R., Huang, X., Fang, Y., \& Liu, L. (2015). Classification of Ultra-High Resolution Orthophotos Combined with DSM Using a Dual Morphological Top Hat Profile. Remote Sensing, 7(12), 16422-16440. https://doi.org/10.3390/rs71215840. 